\title{
Kajian Sifat Fisikokimia dan Organoleptik Beras Singkong (Manihot Esculenta Crantz) Dengan Modifikasi Secara Pemanasan
}

\section{Study Of Physicochemical and Organoleptic Properties of Cassava Rice (Manihot Esculenta Crantz) by Heating Modification}

\author{
Ardiansyah $^{1 *}$ dan Endang Sri Wahyuni \\ ${ }^{1}$ Jurusan Gizi Politeknik kesehatan Tanjungkarang kemenkes RI \\ *E-mail : ardiansyah9msi@gmail.com
}

\begin{abstract}
This study aims to determine the effect of heating on physicochemical properties of cassava flour by modifying the heating and organoleptic of cassava rice with cassava flour modified heating. The experimental design used in this study was a completely randomized design, consisting of one factor with six levels of treatment namely 0 minutes warm-up time, 15 minutes, 30 minutes, 45 minutes 60 minutes and 75 minutes. The results of the study data were analyzed by anova test and carried out by the Tukey HSD test. From the results of the study it was concluded that there was a warming effect on digestibility, cassava starch resistant starch modified heating. Cassava rice with cassava flour modified heating is not liked by panelists.
\end{abstract}

Keywords: digestibility, resistant starch, heating

Disubmit : 02 April 2019 ; Diterima: 14 Juni 2019 ; Disetujui: 24 Agustus 2019

\section{PENDAHULUAN}

Makanan pokok utama bagi rakyat Indonesia adalah beras, gannguan ketersedian makanan pokok ini akan menimbulkan kerawanan sosial yang membahayakan stabiliatas ekonomi dan stabilitas Nasional, Pemerintah berusahan agar ketersedihan bahan pangan ini tetap terjaga, karena beras adalah makan pokok yang paling penting. Demi untuk menjaga ketahanan pangan terutama beras segala upaya pemerintah dilakukan baik dengan meningkatkan produksi beras sampai mengimpor beras dari luar negri dilakukan. Kebijakan Impor oleh pemerintah menjadi polemik ditengah masyarakat Protes para petani tentang kebijakan impor beras dari negara lain menjadi kisruh politik nasional, karena para petani import beras dapat menurutkan daya jual hasil panen mereka.

Diversifikasi pangan lokal yang bebasis singkong kurang diupayakan dikarenakan adanya pendapat bila mengkomsumsi singkong dapat berdampak terjadinya kurang gizi terutama kekurangan protein. Konsumsi bahan pangan pokok dari singkong bila diikuti dengan konsumsi sumber protein yang cukup tidak akan menimbulkan kekurangagn gizi. Menurut (Bezerra, dan S, 2011), diversifikasi pangan dapat meningkatkan status gizi dan dapat mengurangi makanan yang kurang sehat untuk dikomsumsi. Singkong mengandung sumber pati yang dapat dimodifikasi yang menghasilkan pati resisten. Bahan pangan yang mengandung pati resisten termasuk pangan fungsional yang bermanfaat bagi kesehatan.. Menurut (Perez, 2005), pati resisten didefinisikan sebagai sejumlah pati dan hasil degradasi pati yang tidak dapat dihidrolisis oleh enzim sehingga tidak dapat diserap oleh usus halus manusia yang sehat. 
Teknik modifikasi pati dapat dilakukan dengan baik secara fisik maupun kimia. Salah satu teknik modifikasi pati secara fisik yang banyak digunakan yaitu melalui pemanasan dan pendinginan dengan produk akhir adalah pati resisten atau resistant starch Proses pemanasan-pendinginan merupakan gabungan proses gelatinisasi dan retrogradasi, selama proses pemanasan struktur granula pati akan mengalami kerusakan dan saat pendinginan akan terjadi kristalisasi kembali komponen pati baik amilosa maupun amilopektin (retrogradasi) (Perez, 2005). Modifikasi fisik cenderung lebih aman karena tidak menggunakan berbagai pereaksi kimia. Perlakuan modifikasi secara fisik antara lain: ekstrusi, parboiling, steam-cooking, iradiasi microwave, pemanggangan, hydrothermal treatment, dan autoclaving (Sajilata, 2006). Sebagian besar metode modifikasi fisik yang telah disebutkan dapat meningkatkan kadar pati resisten (Sajilata, 2006).

Penelitian ini bertujuan mengetahui pengaruh pemanasan terhadap sifat fisikokimia tepung singkong dengan modifikasi pemanasan dan organoleptik beras singkong dengan tepung singkong modifikasi pemanasan. Kajian sifat fisikokimia meliputi : daya cerna pati, pati resisten, serat larut, serat tidak larut dan total serat pangan. Sifat organoleptik wrana, aroma, tekstur dan rasa beras singkong dengan tepung singkong modifikasi pemanasan.

\section{METODE PENELITIAN}

Penelitian ini menggunakan metode eksperimen yang disusun dalam Rancangan penelitian : Pertama pembuatan tepung singkong dengan metode pemanasan oven dengan suhu $150{ }^{\circ} \mathrm{C}$ dengan waktu $0,15,30$, 45, 60, 75 menit. Analisis sifat fisikokimia yang terdiri dari analsis daya cerna pati, pati resisten, serat pangan tidak larut (IDF), serat pangan larut (SDF) dan total serat. Kedua Pembuatan beras singkong dengan tepung singkong modifikasi pemanasan, beras singkong di uji organoleptik warna, aroma, tekstur dan rasa kepada 30 panelis. Penelitian ini dilakukan pada bulan Agustus 2018 di laboratorium Teknologi Hasil Pertanian Universitas Lampung dan Poltekkes Tanjungkarang Jurusan Gizi.

Alat dan bahan yang digunakan berupa singkong varietas kasetsart yang banyak dibudidayakan di propinsi Lampung. bahan lainnya adalah bahan kimia untuk analisis kimia. Peralatan yang digunakan meliputi alat pemotong alat penepung, alat pemanasan oven, alat pencetak beras

\section{Pembuatan tepung Singkong}

Singkong disortasi dan ditimbang lalu dilakukan pengupasan kulit singkong, setelah dikupas lalu dicuci dengan air hingga bersih ditiskan lalu potong kecil atau dibelah tipis setelah dilakukan pemanasan dengan oven dengan suhu $150{ }^{\circ} \mathrm{C}$ dengan waktu masing-masing $0,15,30,45,60,75$ menit, selanjutnya dilakukan penepungan untuk setiap perlakuan, tepung selanjutnya dilakukan pengayakan dengan saring 80 mesh untuk mendapatkan tepung yang halus, setelah itu lakukan analisis daya cerna pati, analisis pati resisten, analisis serat pangan tidak larut (IDF), analisis serat pangan larut (SDF) dan total serat pangan (TDF)

\section{Pembuatan beras singkong}

Tepung singkong modifikasi pemanasan dilakukan pengadonan dengan penambahan air sedikit demi sedikit sampai tercampur dengan rata dan membentuk adonan. Selanjutnya dilakukan penapihan adonan, lalu dicetak dengan alat pencetak hingga dihasilkan butiran beras, lalu dijemur dengan sinar matahari hingga kering atau kadar air kurang dari 20\%. Beras singkong dilakukan uji organoleptik kepada 30 panelis.

\section{Analisis data}

Semua data yang diperoleh dianalisis secara deskriptif. 


\section{HASIL DAN PEMBAHASAN \\ Daya cerna pati}

Daya cerna pati adalah kemampuan enzim pemecah pati dalam menghidrolisis pati menjadi unit-unit yang lebih kecil (gula-gula yang lebih sederhana). Daya cerna pati tepung singkong dengan modifikasi pemanasan dapat dilihat pada gambar 1

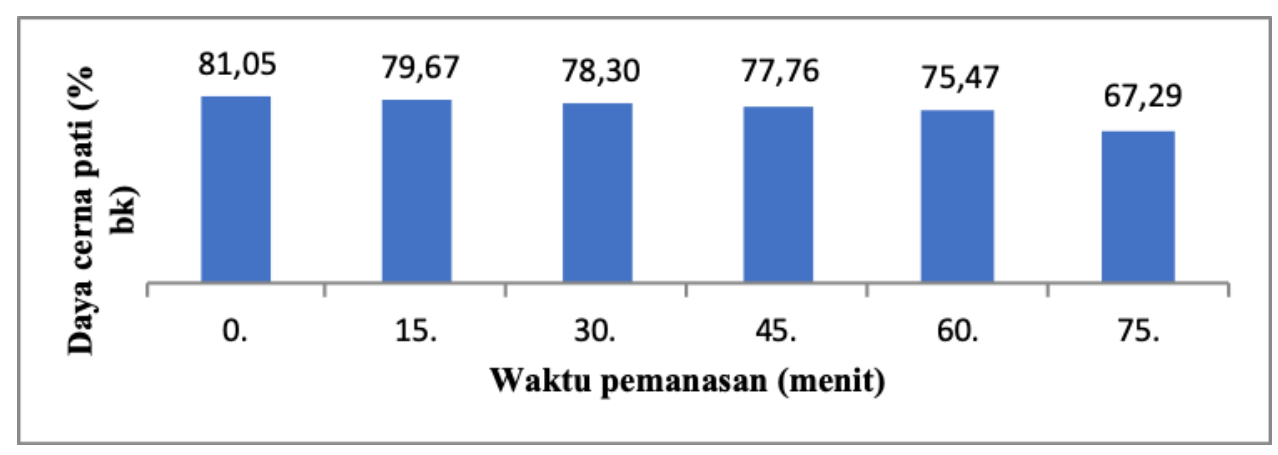

Gambar 1. Daya cerna pati tepung singkong modifikasi dengan waktu pemanasan

Gambar 1 menunjukkan terjadi penurunan daya cerna pati pada setiap perlakuan waktu pemanasan dibandingkan dengan tanpa pemanasan, penurunan daya cerna pati akan meningkat kadar pati resisten. Hasil ini berbeda dengan peneltian yang dilakukan sebelumnya, bahwa kombinasi fermentasi 24 jam dengan pemanasan autoklaf meningkatkan daya cerna pati tepung pisang dibandingkan dengan kontrol tanpa pemanasan aouklaf (Fatimah, 2010). Penurunan daya cerna pati tepung beras singkong diduga karena adanya perubahan pigmen warna kecoklatan yang menyebabkan daya cerna pati tepung singkong lebih rendah dibanding dengan tanpa pemanasan yang berwarna putih. Daya cerna pati juga dipengaruhi oleh pigmen (tannin dan polifenol) yang dapat menghambat aktivitas enzimatis, seperti daya cerna pati jagung kuning lebih rendah dibandingkan dengan daya cerna pati jagung putih (Adejumo, A.L, F.A Aderibigbe, 2013).

Hasil Uji anova daya cerna pati tepung singkong modifikasi pemanasan dengan nilai signifikat $<0,05$ hal ini menunjukkan ada pengaruh perlakuan lama pemanasan terhadap daya cerna pati tepung singkong, dan hasil uji lanjut Tukey HSD antar perlakuan P0 (0 menit) dengan P2 (30 menit), P3 (45 menit), P4 (60 menit) dan P5 (75 menit) didapatkan nilai signifikat $<0,05$ berarti ada perbedaan yang signifikat antar perlakuan P0 (0 menit) dengan P2 (30 menit), P3 (45 menit), P4 (60 menit) dan P5 (75 menit), sedangkan perlakuan P0 (0 menit) dengan Perlakuan P1 (15 menit) didapatkan nilai signifikat $>0,05$ berarti tidak ada perbedaan signifikat antar perlakuan P0 (0 menit) dengan Perlakuan P1 (15 menit. Perlakuan P0 (0 menit) tidak berbeda nyata dengan P1 (15 menit).

\section{Pati resisten}

Pati resisten adalah pati yang tidak dapat dicerna oleh enzim pencernaan di usus halus dan ketika sampai di usus besar dapat dimanfaatkan oleh probiotik. Pati resisten memiliki potensi efek fisiologisdalam usus halus dan usus besar. Mengkomsumsi makanan yang mengandung kadar pati resisten berpengaruh terhadap respon insulin yang lebih rendah dibandinkan dengan mengkomsumsi makanan yang tidak mengandung atau sedikit mengandung pati resisten. pati resisten digolongkan sebagai serat pangan. Pati resisten tepung singkong dengan modifikasi pemanasan dapat dilihat pada Gambar 2. 


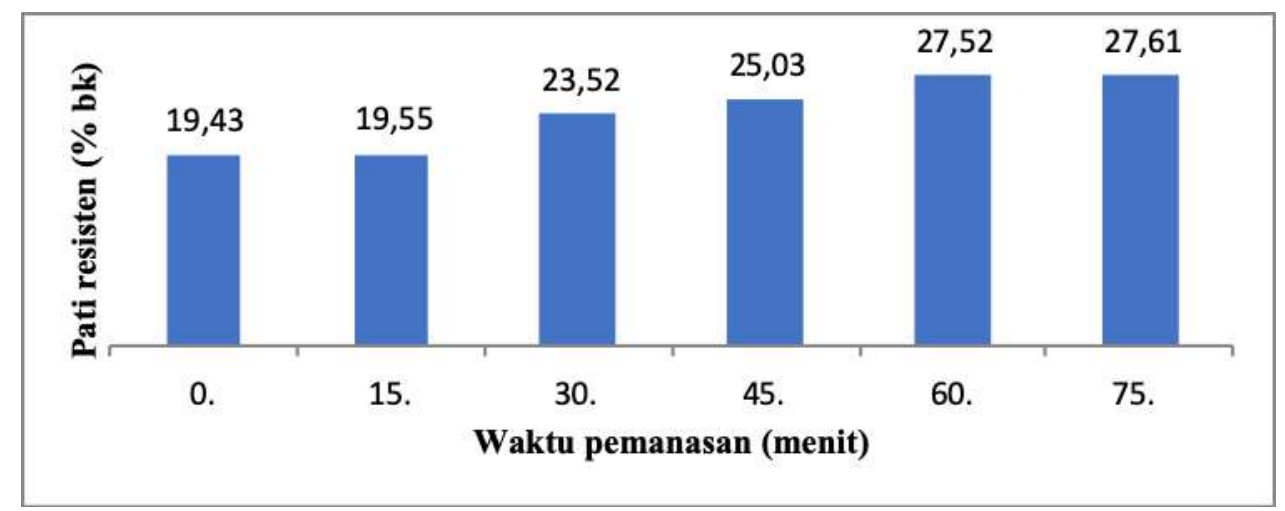

Gambar 2. Pati resisten tepung singkong dengan modifikasi pemanasan

Gambar 2 menunjukkan ada kenaikan kadar pati resisten tepung singkong dengan modifiksi pemanasan. Baking atau pemanggangan pati dapat meningkat kadar pati resisten (Westerlund, E., O. Theander, R. Andersson, 1989). Penelitian yang sesuai dengan penelitian ini menyimpulkan kombinasi fermentasi 24 jam dengan pemanasan autoklaf meningkatkan kadar pati resisten tepung pisang dua kali lipat dibandingkan dengan kontrol tanpa pemanasan aouklaf (Fatimah, 2010).

Hasil Uji anova kadar pati resiten tepung singkong modifikasi pemanasan dengan nilai signifikat < 0,05 hal ini menunjukkan ada pengaruh perlakuan waktu pemanasan terhadap kadar pati resisten tepung singkong dan hasil uji lanjut Tukey HSD antar perlakaun P0 (0 menit) dengan perlakuan P2 (30 menit), P3 (45 menit) P4 (60 menit) dan P5 (75 menit) didapatkan nilai signifikat $<0,05$ berarti ada perbedaan yang signifikat antar perlakuan P0 (0 menit) dengan perlakuan P2 (30 menit), P3 (45 menit) P4 (60 menit) dan P5 (75 menit, sedangkan pada perlakuan P0 (0 menit) dengan P1 (15 menit) didapatkan nilai signifikat >0,05 berarti tidak ada perbedaan antar perlakuan P0 (0menit) dengan P1 (15 menit)

\section{Serat pangan tidak larut (IDF)}

Serat pangan tidak larut/insduble dietary fiber (IDF) diartikan sebagai serat pangan yang tidak larut dalarn air panas rnaupun dngin. Serat pangan tidak larut (IDF) tepung beras singkong dengan modifikasi pemanasan dapat dilihat pada Gambar 3

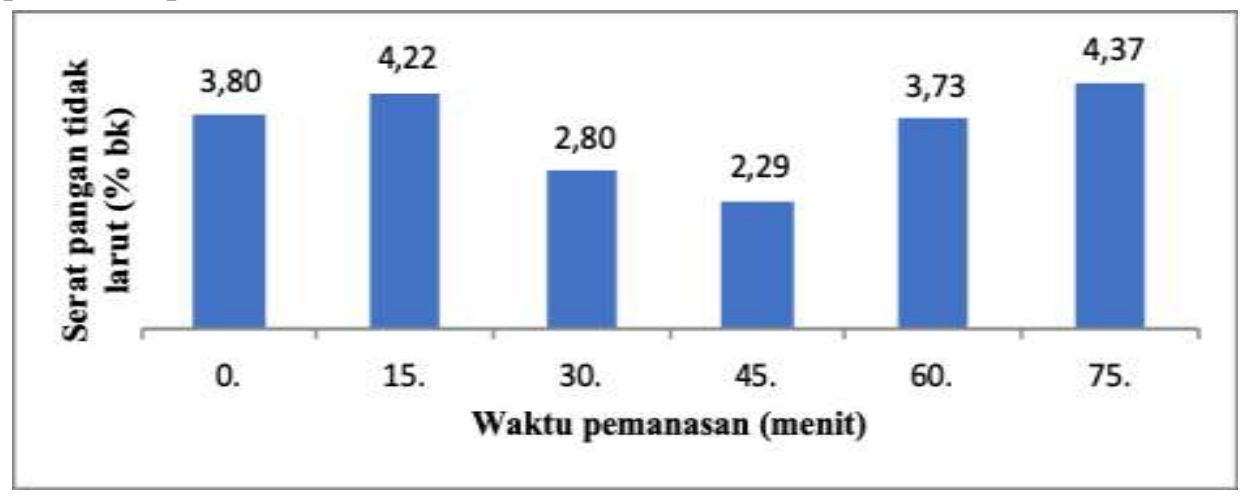

Gambar 3, Serat pangan tidak larut (IDF) tepung singkong dengan modifikasi pemanasan

Gambar 3 menunjukkan terjadi kenaikan kadar serat pangan tidak larut tepung singkong modifikasi pemanasan. Perlakuan P2 (15 meni)t dan P6 (75 menit) dibandingkan dengan kontrol dan terjadi penurunan kadar serat pangan tidal larut pada perlakuan P3 (30 meni) dan P4 (45 menit) dan P5 (60 menit) dibandingkan dengan tanpa pemanasan. Serat pangan tidak larut serat pangan yang tidak larut dalam air panas dan dingin (Muchtadi, 2001). Serat tidak larut dapat mempertahankan matriks strukturalnya dari air 
membentuk campuran yang vikositasnya rendah yang mengakibatkan massa feses yang rendah dan mempersingkat waktu transit (Kin, 2000)

Hasil Uji anova kadar serat pangan tidak larut tepung singkong modifikasi pemanasan dengan nilai signifikat $>0,05$ ) hal ini menunjukkan tidak ada pengaruh pemanasan terhadap kadar serat pangan tidak larut tepung singkong modifikasi pemanasan dan hasil uji lanjut Tukey HSD antar perlakuan P0 (0 menit) dengan perlakuan P1 (15 menit, P2 (30 menit) P3 (45 menit), P4 (60 menit) dan P5 (75 menit) didapatkan nilai signifikat $>0,05$ berarti tidak ada perbedaan yang signifikat antar perlakuan P0 (0 menit) dengan perlakuan P1 (15 menit, P2 (30 menit) P3 (45 menit), P4 (60 menit) dan P5 (75 menit) terhadap k serta pangan tidak lariut tepung singkong.

\section{Serat pangan larut (SDF)}

Serat pangan larut/ Soluble Dietary Fiber (SDF) diartikan sebagai serat pangan yang dapat larut dalarn air hangat atau panas. Serat pangan larut (SDF) tepung beras singkong dengan modifikasi pemanasan dapat dilihat pada Gambar 4.

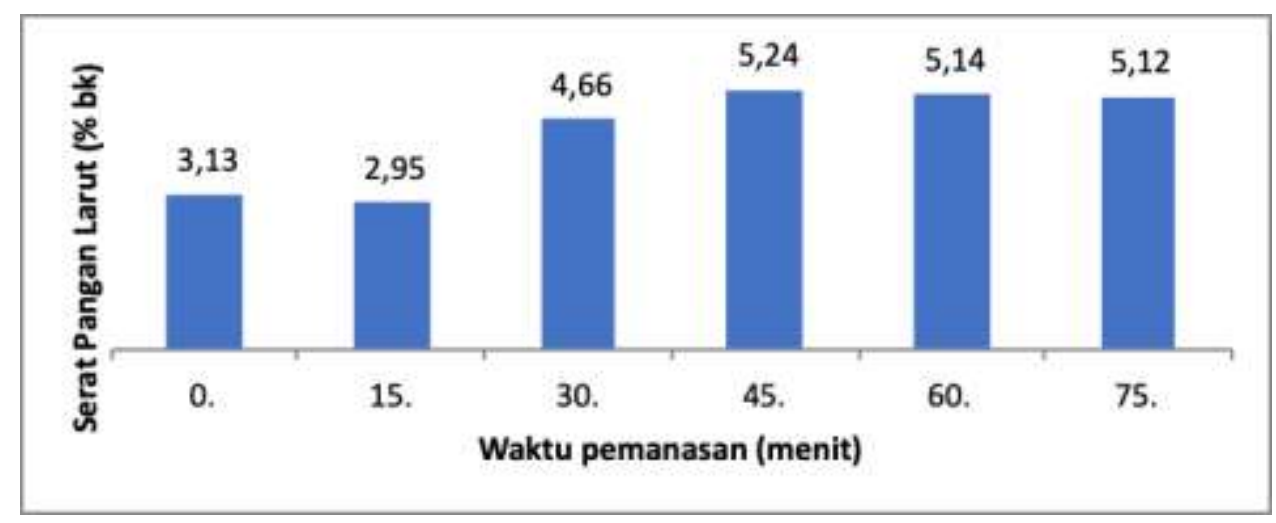

Gambar 4. Serat larut (SDF) tepung singkong dengan modifikasi pemanasan

Gambar 4 menunjukkan terjadi kenaikan kadar serat pangan larut dibandingkan dengan kontrol kecuali pada perlakuan P2 (15 menit) terjadi penurunan kadar serat larut tepung singkong modifikasi pemanasan. Serat pangan larut adalah serat pangan yang dapat larut pada air panas dan dingin (Muchtadi, 2001). Serat larut ketika berada dalam di usus halus akan membentuk larutan yang memiliki vikositas yang tinggi karena yang dapat mempengaruhi metabolisme lipid dan karbohidrat dan sebagian memiliki pontensi antikarsinogenik (Kin, 2000).

Hasil Uji anova serat pangan larut tepung singkong modifikasi pemanasan dengan nilai signifikat < $0,05)$ hal ini menunjukkan ada pengaruh perlakuan modifikasi pemanasan terhadap kadar serat pangan larut tepung beras singkong dan hasil uji lanjut Tukey HSD antar perlakuan P0 (0 menit) dengan perlakuan P1 (15 menit, P2 (30 menit) P3 (45 menit), P4 (60 menit) dan P5 (75 menit) didapatkan nilai signifikat > 0,05 berarti tidak ada perbedaan yang signifikat antar perlakuan P0 (0 menit) dengan perlakuan P1 (15 menit, P2 (30 menit) P3 (45 menit), P4 (60 menit) dan P5 (75 menit) terhadap kadar serta pangan lariut tepung singkong.

\section{Total Serat pangan (TDF)}

Total Serat pangan/total dietary fiber, (TDF) terdiri dari komponen serat pangan larut/Soluble Dietary Fiber (SDF) dan serat pangan tidak larut (Insduble Dietary Fiber (IDF). Total serat Pangan (TDF) tepung singkong dengan modifikasi pemanasan dapat dilihat pada Gambar 5. 


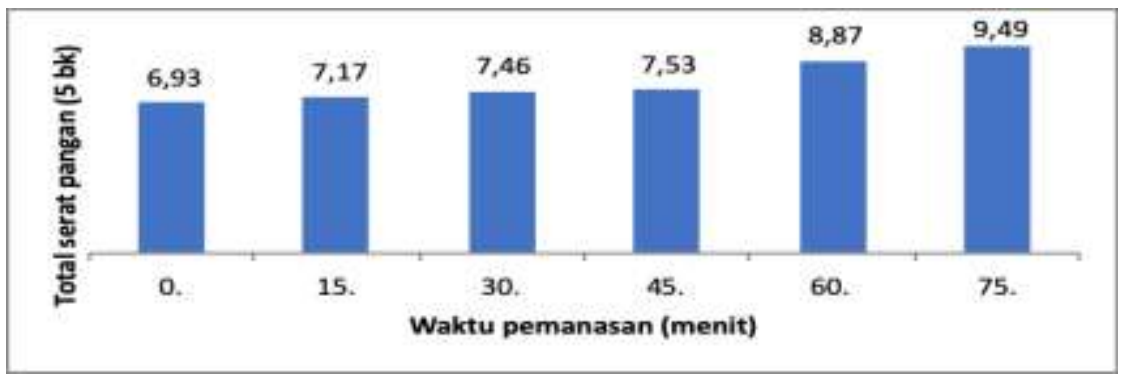

Gambar 5. Total serat Pangan (TDF) tepung singkong dengan modifikasi pemanasan

Gambar 5 menunjukkan ada kenaikan kadar total serat pangan tepung singkong modifiksi dengan pemanasan. Penelitian yang telah dilakukan dan sesuai dengan penelitian menyimpulkan pemanasan dengan otoklaf dapat meningkatkan kadar total serat pangan (Fatimah, 2010). Peningkatan kadar total serat pangan tepung beras singkong menunjukkan adanya peningkatan kadar pati resisten. Hasil ini sama dengan pati garut yang dimodifikasi dengan pemnasan otoklaf kadar total serat pangan meningkat akibat terbentuknya pati resisten (Sugiyono, P.Ratih, dan D.N, 2009)

Hasil Uji anova kadar total serat pangan tepung singkong modifikasi pemanasan dengan nilai signifikat $<0,05)$ hal ini menunjukkan ada pengaruh pemanasan terhadap kadar total serat pangan tepung singkong modifikasi pemanasan dan hasil uji lanjut Tukey HSD antar perlakuan P0 (0 menit) dengan perlakuan P2 (30 menit) P3 (45 menit), P4 (60 menit) dan P5 (75 menit) didapatkan nilai signifikat > 0,05 berarti ada perbedaan yang signifikat antar perlakuan P0 (0 menit) dengan perlakuan P2 (30 menit) P3 (45 menit), P4 (60 menit) dan P5 (75 menit) terhadap kadar serta pangan tidak lariut tepung singkong.

\section{Uji Organoleptik (warna, aroma, tekstur dan rasa) beras singkong dengan tepung singkong modifikasi} pemanasan

\section{a. Pemanasan 0 menit}

Tabel 1. Hasil uji organoleptik (warna, aroma tekstur dan rasa) beras singkong dengan tepung singkong modifikasi pemanasan 0 menit

\begin{tabular}{|c|c|c|c|c|c|}
\hline Indikator & Katagori & Panelis & Skor & Total skor & $(\%)$ \\
\hline \multirow[t]{4}{*}{ Warna } & Sangat suka & 20 & 80 & 102 & 85,00 \\
\hline & Suka & 5 & 15 & & \\
\hline & Tidak suka & 2 & 4 & & \\
\hline & Sangat tidak suka & 3 & 3 & & \\
\hline \multirow[t]{4}{*}{ Aroma } & Sangat suka & 3 & 12 & 49 & 40,83 \\
\hline & Suka & 2 & 6 & & \\
\hline & Tidak suka & 6 & 12 & & \\
\hline & Sangat tidak suka & 19 & 19 & & \\
\hline \multirow[t]{4}{*}{ Tekstur } & Sangat suka & 4 & 16 & 66 & 55,00 \\
\hline & Suka & 6 & 18 & & \\
\hline & Tidak suka & 12 & 24 & & \\
\hline & Sangat tidak suka & 8 & 8 & & \\
\hline \multirow[t]{6}{*}{ Rasa } & Sangat suka & 2 & 8 & 56 & 46,67 \\
\hline & Suka & 3 & 9 & & \\
\hline & Tidak suka & 14 & 28 & & \\
\hline & Sangat tidak suka & 11 & 11 & & \\
\hline & Total skor & & & 273 & 56,88 \\
\hline & Rarata skor & & & 68,25 & \\
\hline
\end{tabular}


Tabel 1 menunjukkan hasil analisis organoleptik beras singkong dengan tepung singkong modifikasi pemanasan 0 menit dengan panelis sebanyak 30 panelis orang hasil penilaian panelis untuk warna 85,00\% (sangat suka) aroma 40,83\% (sangat tidak suka), tekstur 55,00 \% (tidak suka) rasa 46,67\% (tidak suka) total penilain $56,87 \%$ (tidak suka). Warna beras singkong perlakuan P0 (kontrol) sangat suka $(85,00 \%)$ karena warna putih yang menyerupai beras dan aroma beras singkong P0 (kontrol) sangat tidak suka $(40,83 \%)$ disebabkan bau singkong masih terasa sehingga tidak disukai, tekstur beras singkong tidak suka (55,00\%) disebabkan teksur yang tidak menyerupai beras nasi, rasa beras singkong tidak suka 46,67\% karena rasa beras singkong tidak menyerupai rasa nasi beras. Total skor penilaian beras singkong modifikasi pemanasan P0 (kontrol) 56,87\% atau tidak suka.

\section{b. Pemanasan 15 menit}

Pembuatan tepung singkong modifikasi pemanasan dengan oven dengan suhu $150{ }^{\circ} \mathrm{C}$ selama 30 menit.

Tabel 2. Hasil uji organoleptik (warna, aroma tekstur dan rasa) beras singkong dengan tepung singkong modifikasi pemanasan 15 menit

\begin{tabular}{clclcr}
\hline Indikator & \multicolumn{1}{c}{ Katagori } & Panelis & Skor & Total skor & $(\%)$ \\
Warna & Sangat suka & 18 & 72 & 100 & 83,33 \\
& Suka & 6 & 18 & & \\
& Tidak suka & 2 & 6 & & \\
& Sangat tidak suka & 4 & 4 & & 54,17 \\
Aroma & Sangat suka & 6 & 24 & 65 & \\
& Suka & 4 & 12 & & 61,67 \\
& Tidak suka & 9 & 18 & & \\
& Sangat tidak suka & 11 & 11 & & \\
Rekstur & Sangat suka & 6 & 24 & 74 & \\
& Suka & 7 & 21 & & \\
& Tidak suka & 12 & 24 & & 60,83 \\
& Sangat tidak suka & 5 & 5 & & \\
& Sangat suka & 2 & 8 & 49 & \\
& Suka & 4 & 1 & & \\
& Tidak suka & 16 & 32 & & \\
& Sangat tidak suka & 8 & 8 & & \\
& Total skor & & & 728 & \\
& Rata-rata skor & & & & \\
\end{tabular}

Tabel 2 menunjukan hasil penilaian organoleptik beras singkong dengan tepung singkong modifikasi pemanasan 15 menit dengan nilai untuk warna 83,33\% (sangat suka) aroma 54,17\% (tidak suka), tekstur $61,67 \%$ (tidak suka) rasa 40,83\% (sangat tidak suka) total penilain $60,83 \%$ (tidak suka). Warna beras singkong perlakuan P1 (15 menit) sangat suka $(83,33 \%)$ karena warna putih yang menyerupai beras dan aroma beras singkong P1 (15 menit) tidak suka $(54,17 \%)$ disebabkan bau singkong masih terasa sehingga tidak disukai, tekstur beras singkong tidak suka $(61,67 \%)$ disebabkan teksur yang tidak menyerupai beras nasi, rasa beras singkong sangat tidak suka $(40,83 \%)$ karena rasa beras singkong tidak menyerupai rasa nasi beras. Total skor penilaian beras singkong modifikasi pemanasan P1 (15 menit) 61,67\% atau tidak suka

\section{c. Pemanasan 30 menit}

Pembuatan tepung singkong modifikasi pemanasan dengan oven dengan suhu $150{ }^{\circ}$ Cselama 30 menit. 
Tabel 3. Hasil uji organoleptik (warna, aroma tekstur dan rasa) beras singkong dengan tepung singkong modifikasi pemanasan 30 menit

\begin{tabular}{llclll}
\hline Indikator & \multicolumn{1}{c}{ Katagori } & Panelis & Skor & Total skor & $(\%)$ \\
\hline Warna & Sangat suka & 16 & 64 & 90 & 75,00 \\
& Suka & 4 & 12 & & \\
& Tidak suka & 4 & 8 & & \\
& Sangat tidak suka & 6 & 6 & & 65,83 \\
Aroma & Sangat suka & 9 & 36 & 79 & \\
& Suka & 8 & 24 & & \\
& Tidak suka & 6 & 12 & & \\
& Sangat tidak suka & 7 & 7 & & \\
Tekstur & Sangat suka & 7 & 24 & 71 & \\
& Suka & 6 & 18 & & \\
& Tidak suka & 12 & 24 & & \\
& Sangat tidak suka & 5 & 5 & & \\
& Sangat suka & 2 & 8 & 57 & \\
& Suka & 2 & 6 & & \\
& Tidak suka & 17 & 34 & & \\
& Sangat tidak suka & 9 & 9 & & \\
& Total skor & & & 297 & \\
& Rata-rata skor & & & 74,25 & \\
& & & & & \\
\hline
\end{tabular}

Tabel 3 menunjukkan bahwa hasil penilaian organoleptik beras singkong dengan tepung singkong modifikasi pemanasan 30 menit dengan nilai untuk warna 75,00\% (suka) aroma 65,83\% (suka), tekstur $59,17 \%$ (tidak suka) rasa $47,50 \%$ (tidak suka) total penilain $61,88 \%$ (tidak suka). Warna beras singkong perlakuan P2 (30 menit) suka (75,00\%) karena warna putih yang masih menyerupai beras dan aroma beras singkong P2 (30 menit) suka $(65,83 \%)$ disebabkan bau aroma wangi dan bau singkong sudah berkurang sehingga disukai, tekstur beras singkong tidak suka $(59,17 \%)$ disebabkan teksur yang tidak menyerupai beras nasi, rasa beras singkong sangat tidak suka $(47,50 \%)$ karena rasa beras singkong tidak menyerupai rasa nasi beras. Total skor penilaian beras singkong modifikasi pemanasan P2 (30 menit) 61,88\% atau tidak suka.

\section{d. Pemanasan 45 menit}

Pembuatan tepung singkong modifikasi pemanasan dengan oven dengan suhu $150{ }^{\circ} \mathrm{C}$ selama 45 menit.

Tabel 4. Hasil uji organoleptik (warna, aroma tekstur dan rasa) beras singkong dengan tepung singkong modifikasi pemanasan 45 menit

\begin{tabular}{llclll}
\hline Indikator & Katagori & Panelis & Skor & Total skor & $(\%)$ \\
\hline Warna & Sangat suka & 11 & 44 & 77 & 64,17 \\
& Suka & 4 & 12 & & \\
& Tidak suka & 6 & 12 & & \\
\multirow{5}{*}{ Aroma } & Sangat tidak suka & 9 & 9 & & 72,50 \\
& Sangat suka & 12 & 48 & 87 & \\
& Suka & 9 & 27 & & 61,67 \\
& Tidak suka & 3 & 6 & & \\
& Sangat tidak suka & 6 & 6 & & \\
& Sangat suka & 6 & 24 & 74 & \\
& Suka & 7 & 21 & & \\
& Tidak suka & 12 & 24 & & \\
& Sangat tidak suka & 5 & 5 & & \\
\hline
\end{tabular}


Jurnal Penelitian Pertanian Terapan

\begin{tabular}{llclll}
\hline Rasa & Sangat suka & 2 & 8 & 58 & 48,33 \\
& Suka & 2 & 6 & & \\
Tidak suka & 18 & 36 & & \\
& Sangat tidak suka & 8 & 8 & & \\
Total skor & & & 296 & 61,67 \\
& Rata-rata skor & & & 74,50 & \\
\hline
\end{tabular}

Tabel 4 dapat dilihat hasil penilaian organoleptik beras modifikasi pemanasan P3 (45 menit) dengan nilai untuk warna $64,17 \%$ (suka) aroma $72,50 \%$ (suka), tekstur $61,67 \%$ (tidak suka) rasa 48,33\% (tidak suka) total penilain $61,67 \%$ (tidak suka). Warna beras singkong perlakuan P3 (45 menit) suka (64,17\%) karena warna sedikit tidak putih tapi masih menyerupai warna beras dan aroma beras singkong P3 (45 menit) suka $(72,50 \%)$ disebabkan bau wangi beras singkong sehingga disukai panelis, tekstur beras singkong tidak suka $(61,67 \%)$ disebabkan teksur yang tidak menyerupai beras nasi, rasa beras singkong tidak suka $(48,33 \%)$ karena rasa beras singkong tidak menyerupai rasa nasi beras. Total skor penilaian beras singkong modifikasi pemanasan P3 (45 menit) 61,67 \% atau tidak suka.

\section{e. Pemanasan 60 menit}

Pembuatan tepung singkong modifikasi pemanasan dengen oven suhui $150{ }^{\circ} \mathrm{C}$ selama 60 menit

Tabel 5. Hasil uji organoleptik (warna, aroma tekstur dan rasa) beras singkong dengan tepung singkong modifikasi pemanasan 60 menit

\begin{tabular}{llclll}
\hline Indikator & \multicolumn{1}{c}{ Katagori } & Panelis & Skor & Total skor & $(\%)$ \\
\hline Warna & Sangat suka & 9 & 36 & 75 & 62,50 \\
& Suka & 3 & 15 & & \\
& Tidak suka & 5 & 10 & & \\
& Sangat tidak suka & 13 & 14 & & 74,17 \\
Aroma & Sangat suka & 17 & 56 & 89 & \\
& Suka & 9 & 27 & & 61,67 \\
& Tidak suka & 2 & 4 & & \\
& Sangat tidak suka & 2 & 2 & & \\
Tekstur & Sangat suka & 6 & 24 & 74 & \\
& Suka & 7 & 21 & & \\
& Tidak suka & 12 & 24 & & \\
& Sangat tidak suka & 5 & 5 & & \\
& Sangat suka & 2 & 8 & 54 & \\
& Suka & 2 & 6 & & \\
& Tidak suka & 14 & 28 & & \\
& Sangat tidak suka & 12 & 12 & & \\
& Total skor & & & 294 & \\
& Rata-rata skor & & & 73,50 & \\
& & & & & \\
\hline
\end{tabular}

Tabel 5 menunjukkan bahwa hasil penilaian organoleptik beras singkong dengan tepung singkong modifikasi pemanasan 60 menit dengan nilai untuk warna 62,50\% (suka) aroma $74,17 \%$ (suka), tekstur $61,67 \%$ (tidak suka) rasa 45,00\% (tidak suka) total penilain $61,25 \%$ (tidak suka). Warna beras singkong perlakuan P4 (60 menit) suka $(62,50 \%)$ karena warna sedikit coklat tapi masih agak menyerupai beras dan aroma beras singkong P4 (60 menit) suka $(74,17 \%)$ disebabkan bau wangi beras singkong sehingga disukai panelis, tekstur beras singkong tidak suka $(61,67 \%)$ disebabkan teksur yang tidak menyerupai beras nasi, rasa beras singkong sangat tidak suka $(45,00 \%)$ karena rasa beras singkong tidak menyerupai rasa nasi beras. Total skor penilaian beras singkong modifikasi pemanasan P4 (60 menit) 61,25\% atau tidak suka. 


\section{f. Pemanasan 75 menit}

Pembuatan tepung singkong modifikasi pemanasan dengan oven dengan suhu $150{ }^{\circ} \mathrm{C}$ selama 75 menit.

Tabel 6. Hasil analisis organoleptik (warna, aroma tekstur dan rasa) beras singkong dengan tepung singkong modifikasi pemanasan 75 menit

\begin{tabular}{|c|c|c|c|c|c|}
\hline Indikator & Katagori & Panelis & Skor & Total skor & $(\%)$ \\
\hline \multirow[t]{4}{*}{ Warna } & Sangat suka & 8 & 32 & 70 & 58,33 \\
\hline & Suka & 4 & 12 & & \\
\hline & Tidak suka & 8 & 16 & & \\
\hline & Sangat Tidak suka & 10 & 10 & & \\
\hline \multirow[t]{4}{*}{ Aroma } & Sangat suka & 18 & 72 & 98 & 81,67 \\
\hline & Suka & 6 & 18 & & \\
\hline & Tidak suka & 2 & 4 & & \\
\hline & Sangat Tidak suka & 4 & 4 & & \\
\hline \multirow[t]{4}{*}{ Tekstur } & Sangat suka & 6 & 24 & 74 & 61,67 \\
\hline & Suka & 7 & 21 & & \\
\hline & Tidak suka & 12 & 24 & & \\
\hline & Sangat Tidak suka & 5 & 5 & & \\
\hline \multirow[t]{6}{*}{ Rasa } & Sangat suka & 2 & 8 & 50 & 41,67 \\
\hline & Suka & 2 & 6 & & \\
\hline & Tidak suka & 10 & 20 & & \\
\hline & Sangat Tidak suka & 16 & 16 & & \\
\hline & Total skor & & & 292 & 60,83 \\
\hline & Rata-rata skor & & & 73 & \\
\hline
\end{tabular}

Tabel 6 menunjukkan hasil penilaian organoleptik beras singkong dengan tepung singkong modifikasi pemanasan peralakuan P5 (75 menit) dengan nilai untuk warna 58,33\% (tidak suka) aroma 81,67\% (suka), tekstur $61,67 \%$ (tidak suka) rasa 41,67\% (sangat tidak suka) total penilain 60,83\% (tidak suka) Warna beras singkong perlakuan P5 (75 menit) tidak suka $(58,33 \%)$ karena warna coklat yang tidak menyerupai beras dan aroma beras singkong P5 (75 menit) suka $(81,67 \%)$ disebabkan bau wangi beras singkong sehingga disukai panelis, tekstur beras singkong tidak suka $(61,67 \%)$ disebabkan teksur yang tidak menyerupai beras nasi, rasa beras singkong sangat tidak suka $(41,67 \%)$ karena rasa beras singkong tidak menyerupai rasa nasi beras. Total skor penilaian beras singkong modifikasi pemanasan P5 (75 menit) 60,83\% atau tidak suka.

Warna coklat nonenzim atau reaksi Maillard sangat penting untuk hasil produksi makanan dan hasilnya sangat mungkin dikehendaki mungkin tidak, untuk produk yang reaksinya menguntungkan cirinya produk tersebut warna dan baunya disukai untuk produk yang berbeda bisa warna dan bau tidak disukai (John, 2010)

\section{KESIMPULAN}

Berdasarkan hasil penelitian dan pembahasan maka dapat disimpulkan bahwa pemanasan dapat menurunkan daya cerna pati dan meningkatkan pati resisten tepung singkong. Tepung singkong modifikasi pemanasan menghasilkan tepung yang beraroma harum dan berwarna coklat. Beras singkong dengan tepung singkong modifikasi pemanasan tidak disukai oleh panelis dikarenakan beras yang dihasil berwarna coklat, Saran perlu dialternatif bahan pangan yang cocok untuk penggunaan tepung singkong modifikasi pemanasan

\section{DAFTAR PUSTAKA}

Adejumo, A.L, F.A Aderibigbe, R. U. O. R. (2013) 'Comparative studies of starch susceptibilities to $\alpha$ amylase degradation of different cereal and root crops of Nigeria', J. Biotechnol, 12(29), pp. 46634669. 
Bezerra, dan S, R. (2011) 'Household food diversty and nutritional status among adults in Brazil', Jornal of Behavior Nutrion and Physicol Activity, 8, p. 22.

Fatimah, A. (2010) No TitleModifikasi Pisang Tanduk (Musa paradisiance Formatypica) Memalaui Proses Fermentasi Spontan Dan Pemanasan Otoklaf Untuk Meningkatkan Kadar Pati Resisten, Tesis.

John, M. dan D. (2010) Kimia Pangan.

Kin, Y.-I. (2000) 'Aga Technical Review Limpacto Of Dietery Fiber on Colon Cancer Occurrence Gastroenterology', 118, pp. 1235-1257.

Muchtadi, D. (2001) 'Sayuran Sebagai Sumber Serat Pangan Untuk Mencegah Timbulnya Penyakit Degeneratif', J Teknok dan Industri Pangan, 12, pp. 61-71.

Perez, L. A. et al (2005) 'Resistant starch-rich powder prepared by autoclaving ofalami and lintnerized banana starch. Partial Characterization', J. Starch, 57, pp. 405-412.

Sajilata, K. (2006) 'Resistant Starch A Review', Comprehensive Reviews in Food Science and Food Safety, 5.

Sugiyono, P.Ratih, dan D.N, F. (2009) 'Modifikasi Pati Garut (Marantha arundiance)/dengan perlakuan siklus suhu tinggi pendinginan (autoclaving-cooling cycling) untung menghasil pati resisten Tipe III', J. Teknol dan industri pangan, 20(1), pp. 17-24.

Westerlund, E., O. Theander, R. Andersson, and P. A. (1989) 'Effects of baking on polysaccharides in white bread fractions', J. Cereal Sci, 10(2), pp. 149-156. 